\title{
Article
}

\section{Phenylketonuria Diagnosis by Massive Parallel Sequencing and Genotype-Phenotype Association in Brazilian Patients}

\author{
Rafael Hencke Tresbach ${ }^{1,2}\left(\mathbb{D}\right.$, Fernanda Sperb-Ludwig ${ }^{1,2, *(\mathbb{D})}$, Rodrigo Ligabue-Braun ${ }^{3,4} \mathbb{D}^{\text {, Tássia Tonon }}{ }^{1,5}$, \\ Maria Teresinha de Oliveira Cardoso 6,7,8, Romina Soledad Heredia 6,7, Maria Teresa Alves da Silva Rosa ${ }^{6,7}$, \\ Bárbara Cátia Martins ${ }^{6,7}$, Monique Oliveira Poubel ${ }^{6,7}$, Luiz Carlos Santana da Silva ${ }^{9}$, François Maillot ${ }^{10}$ and \\ Ida Vanessa Doederlein Schwartz $1,2,5,11,12$ D
}

\section{check for} updates

Citation: Tresbach, R.H.; SperbLudwig, F.; Ligabue-Braun, R.; Tonon, T.; de Oliveira Cardoso, M.T.; Heredia, R.S.; da Silva Rosa, M.T.A.; Martins, B.C.; Poubel, M.O.; da Silva, L.C.S.; et al. Phenylketonuria Diagnosis by Massive Parallel Sequencing and Genotype-Phenotype Association in Brazilian Patients. Genes 2021, 12, 20. https://dx.doi.org/10.3390/ genes12010020

Received: 27 November 2020 Accepted: 22 December 2020 Published: 25 December 2020

Publisher's Note: MDPI stays neutral with regard to jurisdictional claims in published maps and institutional affiliations.

Copyright: () 2020 by the authors. Licensee MDPI, Basel, Switzerland. This article is an open access article distributed under the terms and conditions of the Creative Commons Attribution (CC BY) license (https: / / creativecommons.org/ licenses/by/4.0/).
1 BRAIN Laboratory (Basic Research and Advanced Investigations in Neurosciences), Hospital de Clínicas de Porto Alegre, Porto Alegre, RS 90035-903, Brazil; tresbach@gmail.com (R.H.T.); tassitonon@gmail.com (T.T.); idadschwartz@gmail.com (I.V.D.S.)

2 Graduate Program in Genetics and Molecular Biology, Universidade Federal do Rio Grande do Sul, Porto Alegre, RS 91501-970, Brazil

3 Graduate Program in Biological Sciences (PPGBio), Universidade Federal de Ciências da Saúde de Porto Alegre, Porto Alegre, RS 90050-170, Brazil; ligabue.braun@gmail.com

4 Department of Pharmaceutical Sciences, Universidade Federal de Ciências da Saúde de Porto Alegre, Porto Alegre, RS 90050-170, Brazil

5 Graduate Program in Medicine: Medical Sciences, Universidade Federal do Rio Grande do Sul, Porto Alegre, RS 90035-003, Brazil

6 Serviço de Triagem Neonatal de Brasília, Brasília, DF 70684-831, Brazil; doencasraras.ses@gmail.com (M.T.d.O.C.); romina.rh@gmail.com (R.S.H.); mariateresagene@yahoo.com.br (M.T.A.d.S.R.); barbaracatiam@gmail.com (B.C.M.); monolivepoubel@gmail.com (M.O.P.)

7 Hospital de Apoio de Brasília, Unidade de Genética, Brasília, DF 70684-831, Brazil

8 Faculdade de Medicina, Universidade Católica de Brasília (UCB), Brasília, DF 71966-700, Brazil

9 Laboratory of Inborn Errors of Metabolism, Institute of Biological Sciences, Federal University of Pará, Belém, PA 66075-110, Brazil; lcss@ufpa.br

10 CHRU et université de Tours, INSERM 1253 “iBrain”, 37032 Tours, France; francois.maillot@univ-tours.fr

11 Medical Genetics Service, Hospital de Clínicas de Porto Alegre, Porto Alegre, RS 90035-903, Brazil

12 Department of Genetics, Universidade Federal do Rio Grande do Sul (UFRGS),

Porto Alegre, RS 91501-970, Brazil

* Correspondence: fsperb@hcpa.edu.br

Abstract: Phenylketonuria (PKU) is a common inborn error of amino acid metabolism in which the enzyme phenylalanine hydroxylase, which converts phenylalanine to tyrosine, is functionally impaired due to pathogenic variants in the $P A H$ gene. Thirty-four Brazilian patients with a biochemical diagnosis of PKU, from 33 unrelated families, were analyzed through next-generation sequencing in the Ion Torrent PGM ${ }^{\mathrm{TM}}$ platform. Phenotype-genotype correlations were made based on the BioPKU database. Three patients required additional Sanger sequencing analyses. Twenty-six different pathogenic variants were identified. The most frequent variants were c.1315+1G>A $(n=8 / 66)$, c.473G >A $(n=6 / 66)$, and c.1162G>A $(n=6 / 66)$. One novel variant, c.524C $>$ G (p.Pro175Arg), was found in one allele and was predicted as likely pathogenic by the American College of Medical Genetics and Genomics (ACMG) criteria. The molecular modeling of p.Pro175Arg indicated that this substitution can affect monomers binding in the PAH tetramer, which could lead to a change in the stability and activity of this enzyme. Next-generation sequencing was a fast and effective method for diagnosing PKU and is useful for patient phenotype prediction and genetic counseling.

Keywords: next-generation sequencing; molecular diagnosis; phenylketonuria; phenylalanine hydroxylase; $P A H$ 


\section{Introduction}

Phenylketonuria (PKU, OMIM \#261600) is an autosomal recessive inborn error of metabolism in which the conversion of phenylalanine (Phe) to tyrosine by the phenylalanine hydroxylase (EC 1.14.16.1) is defective, resulting in partial or total inactivity of the conversion due to biallelic variants in the $P A H$ gene [1]. Untreated Phe accumulation leads to irreversible neurological effects, such as impaired cognitive development in children and seizures [2].

The treatment for PKU consists of Phe-free dietary management and supplementation with the Phe-free metabolic formula $[3,4]$. The use of sapropterin dihydrochloride may be also recommended for tetrahydrobiopterin $\left(\mathrm{BH}_{4}\right)$-responsive patients [5].

In Brazil, the public health system neonatal screening program performs biochemical screening for PKU by the detection of Phe in dried blood spots (DBS). If the results are abnormal, an additional blood sample is requested to confirm the diagnosis and begin treatment. The confirmatory test includes the measurement of blood Phe and tyrosine concentrations [6].

The $P A H$ gene comprises 13 exons and 12 introns, resulting in a 452-residue protein. Worldwide, about 1188 variants in the $P A H$ gene have been described in the PAHvdb (http: / / www.biopku.org) and about 1013 variants in the Human Gene Mutation Database (HGMD, http:/ / www.hgmd.cf.ac.uk) [7]. The molecular investigation is sometimes the key to concluding the diagnosis of PKU and, consequently, assists in improving the treatment. The gold standard for gene variant detection in PKU patients is Sanger sequencing, which is costly and time-consuming [8]. Next-generation sequencing allows massive parallel deep-level sequencing, i.e., analyzing the entire exome or a targeted gene panel, which results in increased diagnostic sensitivity, faster sequencing and an inexpensive process [9]. $P A H$ genotype data can be used for the prediction of $\mathrm{BH} 4$ responsiveness [9].

This study aimed to perform a molecular diagnosis of Brazilian PKU patients through massive parallel sequencing to confirm the diagnosis and obtain new data that can improve the choice of treatment for some patients.

\section{Materials and Methods}

\subsection{Subjects}

A total of 34 (33 nonrelated) nonconsanguineous PKU patients were recruited (female $=18$, classic PKU $=22$, mild PKU $=10$, and undefined PKU type $=2$ ), of whom 7 had complete previous genotyping, and 7 had incomplete previous genotyping. Of the total cohort, 23 patients were seen at the HCPA Medical Genetics Service (Porto Alegre, Rio Grande do Sul-RS, Brazil), and 11 were seen at the Hospital de Apoio de Brasília Neonatal Service on Newborn Screening, Genetics Unit (Distrito Federal-DF, Brazil).

For the patients from $\mathrm{RS}$, a $\mathrm{BH}_{4}$ deficiency was previously excluded by the measurement of 6,7-dihydropteridine reductase (DHPR) activity in the blood or DBS and of biopterins and neopterins in urine or DBS. Information such as the Phe level at diagnosis, age at diagnosis, age at treatment initiation, $\mathrm{BH}_{4}$ responsiveness [10,11], and previous genotyping diagnosis of the patients were obtained retrospectively from the medical records.

\subsection{DNA Extraction and Sequencing}

Total blood samples were collected, and DNA extraction was performed with an EasyDNA gDNA Purification Kit (Thermo Fisher Scientific, Waltham, MA, USA), according to the manufacturer's instructions. The DNA samples were quantified in Qubit (Thermo Fisher Scientific).

A targeted gene panel was designed using the Ion AmpliSeq Designer (Thermo Fisher Scientific) to include all the exonic regions and intron-exon boundaries of the $P A H$ gene and of the genes causing $\mathrm{BH}_{4}$ deficiencies (GCH1, GCHFR, PTS, PCBD1, QDPR, and SPR). Genomic DNA libraries were prepared using an Ion AmpliSeq ${ }^{\mathrm{TM}}$ Library Kit 2.0 (Thermo Fisher Scientific), followed by purification with magnetic beads (AMPure beads). The samples were sequenced in an Ion Torrent PGM Platform (Thermo Fisher Scientific, server 
version 5.0, Waltham, MA, USA), with a minimal coverage of 250X at the Unidade de Pesquisa Laboratorial (Centro de Pesquisa Experimental, Hospital de Clínicas de Porto Alegre).

Massive parallel sequencing data were analyzed using Torrent Suite 5.0.5 (Thermo Fisher Scientific) to perform the base-calling procedure. IGV 2.8.2 [12] was used for detection of the depth of sequencing and coverage failures that could suggest deletions. Variants were filtered by Enlis Genome Research (Enlis Genomics, Berkeley, CA, USA) and Ion Reporter software (Thermo Fisher Scientific), as well as the following databases: ClinVar, Phenylalanine Hydroxylase Gene Locus-Specific (PAHvdb) [9], and Human Gene Mutation Database.

Novel, conflicting and phase undetermined variants were confirmed by automated Sanger sequencing in an ABI 3500 Genetic Analyzer (Applied Biosystems, Foster City, CA, USA). The results were analyzed in Chromas 2.6.1 (Technelysium, South Brisbane, Australia), and NM_000277.3 and NP_000268.1 were used as the reference sequences.

Previous genotypes were identified through the Sanger sequencing method.

\subsection{Pathogenicity Determination and Prediction}

To determine the pathogenicity of the novel variant, the following variables were considered: allele frequency $<1 \%$ in gnomAD [13] and ABraOM [14]. The American College of Medical Genetics and Genomics (ACMG) guidelines for interpreting variants were used [15].

\subsection{Genotype-Phenotype Analysis}

Genotype-phenotype associations were made through BioPKU database entries [16] and biochemical classification (classic, mild, or undefined PKU), as previously described by Nalin et al. [17], using as the main criteria the Phe level at diagnosis (classic: $>1200 \mu \mathrm{Mol} / \mathrm{L}$ and mild: $360-1200 \mu \mathrm{Mol} / \mathrm{L}$ ).

\subsection{Molecular Modeling}

The tridimensional structure of wild-type phenylalanine hydroxylase was taken from Protein Data Base (PDB) ID 6HYC [18], which also served as a template for tetramer reconstruction. The point mutations were modeled with DeepView [19], while the frameshift and early stop codon variants were modeled with I-TASSER [20]. FoldX 5.0 (AnalyseComplex command) was used to inspect the possible differences in binding affinity between monomers in the PAH tetramer. The differences between the energies of the mutant and wild-type proteins $(\Delta \Delta \mathrm{G}=\Delta \mathrm{Gmut}-\Delta \mathrm{Gwt})$ were considered significant above $1.6 \mathrm{kcal} / \mathrm{mol}$. This value corresponds to twice the intrinsic standard deviation of FoldX [21] and should significantly affect the stability of the variant [22].

\section{Results}

The clinical, biochemical, and genotypic results are presented in Table 1. The sample's median age at diagnosis was 37 [interquartile (IQ) 27-60] days. For the RS patients, the median age at diagnosis was 81.4 (IQ 26.5-88) days and 41 (IQ 34-45.5) days for the DF patients. 
Table 1. Summary of the included phenylketonuria (PKU) patients, including genotypes and clinical information.

\begin{tabular}{|c|c|c|c|c|c|c|c|c|c|c|c|}
\hline Patient & State & Gender & $\begin{array}{c}\text { First Phe } \\
\text { Level } \\
(\mu \mathrm{Mol} / \mathrm{L})\end{array}$ & $\begin{array}{l}\text { Age at } \\
\text { Diagnosis } \\
\text { (Days) }\end{array}$ & $\begin{array}{c}\text { Age at } \\
\text { Treatment } \\
\text { Starting } \\
\text { (Days) }\end{array}$ & $\begin{array}{l}\text { Type } \\
\text { of } \\
\text { PKU }\end{array}$ & NGS Genotype & Previous Genotype & $\begin{array}{l}\text { Type of PKU } \\
\text { According to } \\
\text { BioPKU }^{1}\end{array}$ & $\begin{array}{l}\text { BH4 Respon- } \\
\text { siveness } \\
\text { According to } \\
\text { the Test }\end{array}$ & $\begin{array}{c}\text { BH4 } \\
\text { Responsiveness } \\
\text { According to } \\
\text { BioPKU }^{2}\end{array}$ \\
\hline $1 *$ & RS & $\mathrm{F}$ & 1566 & 26 & 26 & C & $\begin{array}{c}\text { c. } 1222 \mathrm{C}>\mathrm{T}(;) 1222 \mathrm{C}>\mathrm{T} \\
\text { p.Arg } 408 \operatorname{Trp}(;) \operatorname{Arg} 408 \operatorname{Trp}\end{array}$ & $\begin{array}{c}\text { c.1222C }>\mathrm{T}(;) 1222 \mathrm{C}>\mathrm{T} \\
\text { p.Arg408Trp(;)Arg408Trp }\end{array}$ & $\begin{array}{c}\text { Classic } \\
(1832 / 1845)\end{array}$ & $\mathrm{NP}$ & $\begin{array}{l}\text { No }(95 / 98) \text { Yes } \\
(2 / 98) \text { Slow }(1 / 98\end{array}$ \\
\hline $2 * *$ & RS & M & 847 & 28 & 58 & M & $\begin{array}{c}\text { c.524C }>\mathrm{G}(;) 754 \mathrm{C}>\mathrm{T} \\
\text { p.(Pro175Arg)(;)Arg252Trp }\end{array}$ & $\begin{array}{l}\text { c.754C }>\mathrm{T}(;) ? \\
\text { p.Arg252Trp(;)? }\end{array}$ & NA & No ${ }^{* * * * *}$ & NA \\
\hline 3 & RS & $\mathrm{F}$ & 1784 & 36 & 36 & $\mathrm{C}$ & $\begin{array}{c}\text { c. } 1042 C>G(;) 1315+1 G>A \\
\text { p.Leu348Val(;)? }\end{array}$ & $\begin{array}{c}\text { c. } 1042 \mathrm{C}>\mathrm{G}(;) 1315+1 \mathrm{G}>\mathrm{A} \\
\text { p.Leu348Val(;)? }\end{array}$ & Classic $(11 / 16)$ & $\mathrm{NP}$ & No $(5 / 6)$ Yes $(1 / 6)$ \\
\hline 4 & RS & $\mathrm{F}$ & 1478 & 43 & 43 & $\mathrm{C}$ & $\begin{array}{l}\text { c. } 932 \mathrm{~T}>\mathrm{C}(;) 1315+1 \mathrm{G}>\mathrm{A} \\
\text { p.Leu311Pro(;)? }\end{array}$ & c.1315+1G>A(;)? p.?(;)? & Classic $(2 / 2)$ & $\mathrm{NP}$ & NA \\
\hline 5 & RS & M & 417 & 28 & 50 & M & $\begin{array}{l}\text { c.1162G }>A(;) 1169 \mathrm{~A}>\mathrm{G} \\
\text { p.Val388Met(;)Glu390Gly } \\
\text { c.1066-11G>A(;)1169A }>\mathrm{G}\end{array}$ & $\begin{array}{l}\text { c.1162G }>\mathrm{T}(;) ? \\
\text { p.Val388Met(;)? }\end{array}$ & Mild (8/12) & NP & Yes $(11 / 11)$ \\
\hline 6 & RS & $\mathrm{F}$ & 375 & 32 & 66 & M & $\begin{array}{c}\text { p.Gln355_Tyr356insGlyLeuGln } \\
\text { (;)Glu390Gly }\end{array}$ & $\mathrm{NP}$ & Mild (8/14) & $\mathrm{NP}$ & Yes $(8 / 8)$ \\
\hline $7^{* *}$ & RS & M & NA & 60 & 60 & $\mathrm{U}$ & $\begin{array}{c}\text { c. } 842+1 \mathrm{G}>\mathrm{A}(;) 1162 \mathrm{G}>\mathrm{A} \\
\text { p.(?)(;)Val388Met }\end{array}$ & $\begin{array}{c}\text { c. } 842+1 \mathrm{G}>\mathrm{A}(;) 1162 \mathrm{G}>\mathrm{Ap} . ? \\
\text { (;)Val388Met }\end{array}$ & NA & No ${ }^{* * * * *}$ & NA \\
\hline 8 & RS & $\mathrm{F}$ & 562 & 74 & 82 & M & $\begin{array}{l}\text { c.1169A }>\mathrm{G}(;) 1222 \mathrm{C}>\mathrm{T} \\
\text { p.Glu390Gly(;)Arg408Trp }\end{array}$ & $\mathrm{NP}$ & Mild (54/84) & Yes & Yes $(23 / 23)$ \\
\hline 9 & RS & M & 1845 & 102 & 102 & M & $\begin{array}{c}\text { c.722G }>\mathrm{A}(;) 1222 \mathrm{C}>\mathrm{T} \\
\text { p.Arg241His(;)Arg408Trp }\end{array}$ & $\begin{array}{c}\text { c. } 1222 \mathrm{C}>\mathrm{T}(;) 1222 \mathrm{C}>\mathrm{T} \\
\text { p.Arg } 408 \operatorname{Trp}(;) \operatorname{Arg} 408 \operatorname{Trp}\end{array}$ & Mild (25/28) & $\mathrm{No}^{* * * * * *}$ & $\begin{array}{l}\text { Yes }(3 / 6) \text { Slow } \\
(2 / 6) \text { No }(1 / 6)\end{array}$ \\
\hline 10 * & RS & M & 877 & 128 & 156 & M & $\begin{array}{c}\text { c.473G }>A(;) 1162 \mathrm{G}>\mathrm{A} \\
\text { p.Arg158Gln(;)Val388Met }\end{array}$ & $\begin{array}{l}\text { c.1162G>A(;)? } \\
\text { p.Val388Met(;)? }\end{array}$ & Classic (5/7) & No & $\begin{array}{l}\text { Yes }(2 / 3) \text { Slow } \\
(1 / 3)\end{array}$ \\
\hline $11^{* * *}$ & RS & M & 1022 & 195 & 292 & M & $\begin{array}{l}\text { c.[1241A>G];[1042C }>\mathrm{G}] \\
\text { p.[Leu348Val];[Tyr414Cys] }\end{array}$ & $\mathrm{NP}$ & Mild (4/5) & Yes ${ }^{* * * * *}$ & Yes $(3 / 3)$ \\
\hline 12 & RS & $\mathrm{F}$ & 3245 & 5 & 44 & $\mathrm{C}$ & $\begin{array}{l}\text { c.745C }>\mathrm{T}(;) 838 \mathrm{G}>\mathrm{A} \\
\text { p.Leu249Phe(;)Glu280Lys }\end{array}$ & NP & Classic $(1 / 1)$ & NP & NA \\
\hline 13 & RS & $\mathrm{F}$ & 1361 & 15 & 19 & $\mathrm{C}$ & $\begin{array}{c}\text { c.754C }>\mathrm{T}(;) 1222 \mathrm{C}>\mathrm{T} \\
\text { p.Arg252Trp(;)Arg408Trp }\end{array}$ & $\begin{array}{l}\text { c. } 1222 \mathrm{C}>\mathrm{T}(;) ? \\
\text { p.Arg408Trp(;)? }\end{array}$ & $\begin{array}{c}\text { Classic } \\
(103 / 103)\end{array}$ & NP & No $(4 / 4)$ \\
\hline $14^{* * *}$ & RS & $\mathrm{F}$ & 1736 & 16 & 16 & C & $\begin{array}{c}\text { c.[473G>A];[1055delG] } \\
\text { p.[Arg158Gln];[Gly352ValfsTer48] }\end{array}$ & $\mathrm{NP}$ & Classic (1/1) & NP & NA \\
\hline 15 & RS & $\mathrm{F}$ & 2329 & 24 & 24 & $\mathrm{C}$ & $\begin{array}{c}\text { c.712A }>\mathrm{C}(;) 814 \mathrm{G}>\mathrm{T} \\
\text { p.Thr238Pro(;)Gly272Ter }\end{array}$ & NP & Classic $(1 / 1)$ & NP & NA \\
\hline 16 & RS & M & 2716 & 27 & 27 & $\mathrm{C}$ & $\begin{array}{c}\text { c.194T }>C(;) 472 C>\mathrm{T} \\
\text { p.Ile65Thr(;)Arg158Trp }\end{array}$ & c.194T>C(;)? p.Ile65Thr(;)? & Classic $(2 / 2)$ & NP & No $(1 / 1)$ \\
\hline 17 & RS & M & 1697 & 30 & 30 & C & $\begin{array}{c}\text { c.754C }>\text { T(;)1024delG } \\
\text { p.Arg252Trp(;)Ala342HisfsTer58 }\end{array}$ & $\mathrm{NP}$ & NA & NP & NA \\
\hline $18^{* *}$ & RS & $\mathrm{F}$ & 2178 & 27 & 48 & C & $\begin{array}{c}\text { c. } 754 \mathrm{C}>\mathrm{T}(;) 1315+1 \mathrm{G}>\mathrm{A} \\
\text { p.Arg242Trp(;)? }\end{array}$ & c. $1315+1 \mathrm{G}>\mathrm{A}(;)$ ? p.?(;)? & Classic (9/9) & $\mathrm{NP}$ & No $(1 / 1)$ \\
\hline 19 & RS & M & 2904 & 73 & 101 & M & $\begin{array}{c}\text { c.473G }>A(;) 1162 \mathrm{G}>\mathrm{A} \\
\text { p.Arg158Gln(;)Val388Met }\end{array}$ & NP & Classic (5/7) & NP & $\begin{array}{c}\text { No }(2 / 3) \text { Slow } \\
(1 / 3)\end{array}$ \\
\hline
\end{tabular}


Table 1. Cont.

\begin{tabular}{|c|c|c|c|c|c|c|c|c|c|c|c|}
\hline Patient & State & Gender & $\begin{array}{l}\text { First Phe } \\
\text { Level } \\
(\mu \mathrm{Mol} / \mathrm{L})\end{array}$ & $\begin{array}{c}\text { Age at } \\
\text { Diagnosis } \\
\text { (Days) }\end{array}$ & $\begin{array}{l}\text { Age at } \\
\text { Treatment } \\
\text { Starting } \\
\text { (Days) }\end{array}$ & $\begin{array}{l}\text { Type } \\
\text { of } \\
\text { PKU }\end{array}$ & NGS Genotype & Previous Genotype & $\begin{array}{l}\text { Type of PKU } \\
\text { According to } \\
\text { BioPKU }^{1}\end{array}$ & $\begin{array}{l}\text { BH4 Respon- } \\
\text { siveness } \\
\text { According to } \\
\text { the Test }\end{array}$ & $\begin{array}{c}\text { BH4 } \\
\text { Responsiveness } \\
\text { According to } \\
\text { BioPKU }^{2}\end{array}$ \\
\hline 20 & RS & M & 2323 & 4 & 17 & $\mathrm{C}$ & $\begin{array}{c}\text { c. } 1222 \mathrm{C}>\mathrm{T}(;) 1315+1 \mathrm{G}>\mathrm{A} \\
\text { p.Arg408Trp(;)? }\end{array}$ & $\begin{array}{c}\text { c. } 1222 \mathrm{C}>\mathrm{T}(;) 1315+1 \mathrm{G}>\mathrm{A} \\
\text { p.Arg } 408 \operatorname{Trp}(;) ?\end{array}$ & $\begin{array}{l}\text { Classic } \\
(265 / 265)\end{array}$ & NP & No $(40 / 40)$ \\
\hline 21 & RS & M & 2081 & 227 & 233 & $\mathrm{C}$ & $\begin{array}{c}\text { c. } 473 \mathrm{G}>\mathrm{A}(;) 1315+1 \mathrm{G}>\mathrm{A} \\
\text { p.Arg158Gln }\end{array}$ & NP & Classic (29/29) & No ${ }^{* * * * *}$ & No $(6 / 6)$ \\
\hline $22.1^{* * * *}$ & RS & M & 1455 & 670 & 670 & $\mathrm{C}$ & $\begin{array}{l}\text { c. } 782 \mathrm{G}>\mathrm{A}(;) 1315+1 \mathrm{G}>\mathrm{A} \\
\text { p.Arg261Gln(;)? }\end{array}$ & $\begin{array}{l}\text { c. } 782 \mathrm{G}>\mathrm{A}(;) 1315+1 \mathrm{G}>\mathrm{A} \\
\text { p.Arg261Gln(;)? }\end{array}$ & Classic (47/66) & $\mathrm{No}^{* * * * *}$ & $\begin{array}{c}\text { No }(24 / 25) \text { Slow } \\
(1 / 25)\end{array}$ \\
\hline $22.2 * * * *$ & RS & M & 2196 & 2555 & 2677 & C & $\begin{array}{c}\text { c. } 782 \mathrm{G}>\mathrm{A}(;) 1315+1 \mathrm{G}>\mathrm{A} \\
\text { p.Arg261Gln(;)? } \\
\text { c. } 754 \mathrm{C}>\mathrm{T}(;) 1066-11 \mathrm{G}>\mathrm{A}\end{array}$ & $\begin{array}{c}\text { c. } 782 \mathrm{G}>\mathrm{A}(;) 1315+1 \mathrm{G}>\mathrm{A} \\
\text { p.Arg261Gln(;)? }\end{array}$ & Classic $(47 / 66)$ & $\mathrm{No}^{* * * * *}$ & $\begin{array}{c}\text { No }(24 / 25) \text { Slow } \\
(1 / 25)\end{array}$ \\
\hline 23 & $\mathrm{DF}$ & M & 1978 & 39 & 39 & $\mathrm{C}$ & $\begin{array}{c}\text { p.Arg252Trp(;) } \\
\text { Gln355_Tyr356insGlyLeuGln }\end{array}$ & NP & Classic (19/19) & No & No $(6 / 6)$ \\
\hline 24 & $\mathrm{DF}$ & M & 1857 & 18 & 22 & $\mathrm{C}$ & $\begin{array}{c}\text { c. } 168+5 \mathrm{G}>\mathrm{A}(;) 782 \mathrm{G}>\mathrm{A} \\
\text { p.?(;)Arg261Gln }\end{array}$ & NP & Mild (4/5) & Slow & Yes $(2 / 2)$ \\
\hline 25 & $\mathrm{DF}$ & M & 768 & 47 & 47 & M & $\begin{array}{c}\text { c.184delC(;)1169A >G } \\
\text { p.Leu62Ter(;)Glu390Gly }\end{array}$ & $\mathrm{NP}$ & NA & Yes & NA \\
\hline 26 & $\mathrm{DF}$ & $\mathrm{F}$ & 344 & 41 & 41 & M & $\begin{array}{c}\text { c.184delC(;)1169A >G } \\
\text { p.Leu62Ter(;)Glu390Gly }\end{array}$ & $\mathrm{NP}$ & NA & Yes & NA \\
\hline 27 & $\mathrm{DF}$ & $\mathrm{F}$ & 3133 & 38 & 38 & $\mathrm{C}$ & $\begin{array}{l}\text { c.1066-11G>A(;)1066-11G>A } \\
\text { p.Gln355_Tyr356insGlyLeuGln(;)Gln35 }\end{array}$ & 355_Tyr356insG NlyLeuGln & $\begin{array}{l}\text { Classic } \\
(420 / 427)\end{array}$ & Yes & $\begin{array}{c}\text { No }(107 / 114) \text { Slow } \\
(7 / 114)\end{array}$ \\
\hline 28 & DF & $\mathrm{F}$ & 1724 & 41 & 41 & C & $\begin{array}{c}\text { c. } 728 \mathrm{G}>\mathrm{A}(;) 728 \mathrm{G}>\mathrm{A} \\
\text { p.Arg243Gln(;)Arg243Gln }\end{array}$ & $\mathrm{NP}$ & $\begin{array}{l}\text { Classic } \\
(140 / 141)\end{array}$ & No & $\begin{array}{c}\text { No }(13 / 14) \text { Slow } \\
(1 / 14)\end{array}$ \\
\hline 29 & $\mathrm{DF}$ & $\mathrm{F}$ & 1936 & 44 & 44 & $\mathrm{C}$ & $\begin{array}{l}\text { c. } 441+5 \mathrm{G}>\mathrm{T}(;) 473 \mathrm{G}>\mathrm{A} \\
\text { p.Arg158Gln(;)? }\end{array}$ & NP & Classic $(20 / 21)$ & No & $\begin{array}{c}\text { No }(9 / 12) \text { Slow } \\
(3 / 12)\end{array}$ \\
\hline 30 & DF & $\mathrm{F}$ & 2299 & 22 & 22 & $\mathrm{C}$ & $\begin{array}{l}\text { c.184delC(;)184delC } \\
\text { p.Leu62Ter(;)Leu62Ter }\end{array}$ & NP & NA & No & NA \\
\hline 31 & $\mathrm{DF}$ & $\mathrm{F}$ & 1754 & 57 & 57 & C & $\begin{array}{c}\text { c. } 473 \mathrm{G}>\mathrm{A}(;) 782 \mathrm{G}>\mathrm{A} \\
\text { p.Arg158Gln(;)Arg261Gln }\end{array}$ & $\mathrm{NP}$ & Mild (21/36) & Yes & $\begin{array}{l}\text { Yes }(8 / 13) \text { No } \\
(4 / 13) \text { Slow }(1 / 13)\end{array}$ \\
\hline 32 & $\mathrm{DF}$ & $\mathrm{F}$ & NA & 60 & NA & $\mathrm{U}$ & $\begin{array}{c}\text { c.1162G }>\mathrm{A}(;) 1162 \mathrm{G}>\mathrm{A} \\
\text { p.Val388Met(;)Val388Met }\end{array}$ & NP & Classic (23/41) & Yes & $\begin{array}{l}\text { Yes }(9 / 15) \text { No } \\
(4 / 15) \text { Slow }(2 / 15\end{array}$ \\
\hline 33 & $\mathrm{DF}$ & F & 1361 & 30 & 30 & C & $\begin{array}{l}\text { c. } 782 \mathrm{G}>\mathrm{A}(;) 1315+1 \mathrm{G}>\mathrm{A} \\
\text { p.Arg261Gln(;)? }\end{array}$ & $\mathrm{NP}$ & Classic $(47 / 66)$ & Yes & $\begin{array}{c}\text { No }(24 / 25) \text { Slow } \\
(1 / 25)\end{array}$ \\
\hline
\end{tabular}

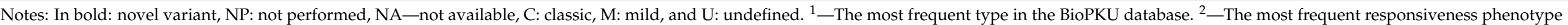

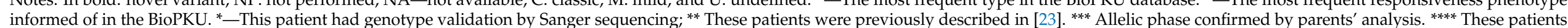
are siblings. ${ }^{* * * * *}$ The BH4 responsiveness results were described by [10]. ${ }^{* * * * * *}$ The BH4 responsiveness results were described by [11]. NGS: next-generation sequencing. 
A total of 26 different pathogenic variants were found in the $P A H$ gene (Table 2). One was a novel variant c.524C $>\mathrm{G}$ (p.Pro175Arg), five were located at the intron-exon boundaries, and twenty were found in exonic regions (Figure 1). The majority $(n=6)$ of the pathogenic variants were found in exon 7 . For the other $\mathrm{BH}_{4}$ metabolism-related genes, no pathogenic variants were found.

Table 2. Variants found in 33 unrelated PKU patients, their references, and American College of Medical Genetics and Genomics (ACMG) classification.

\begin{tabular}{|c|c|c|c|c|c|}
\hline Allele & Protein & Location & Reference & ACMG & Effect \\
\hline c. $168+5 G>A$ & p.? & I 2 & {$[24]$} & PP5 & VUS \\
\hline c.184delC & p.Leu62Ter & E 3 & [25] & PVS1, PM2, PP3, PM4 & Pathogenic \\
\hline c. $194 \mathrm{~T}>\mathrm{C}$ & p.Ile65Thr & E 3 & [26] & PS3, PP2, PP5 & Likely pathogenic \\
\hline c. $441+5 G>T$ & p.? & I 4 & [24] & PP5 & VUS \\
\hline c. $472 \mathrm{C}>\mathrm{T}$ & p.Arg158Trp & E 5 & [27] & PS1, PP2, PP3, PP5 & Likely pathogenic \\
\hline c. $473 \mathrm{G}>\mathrm{A}$ & p.Arg158Gln & E 5 & [28] & PS1, PP2, PP3, PP5 & Likely pathogenic \\
\hline c. $524 \mathrm{C}>\mathrm{G}$ & p.(Pro175Arg) & E 6 & This article & PM2, PM5, PP2, PP3 & Likely pathogenic \\
\hline c. $712 \mathrm{~A}>\mathrm{C}$ & p.Thr238Pro & E 7 & [29] & PM2, PP2, PP3, PP5 & VUS \\
\hline c. $722 \mathrm{G}>\mathrm{A}$ & p.Arg241His & E 7 & [30] & PS1, PS3, PP2, PP3, PP5 & Pathogenic \\
\hline c.728G $>\mathrm{A}$ & p.Arg243Gln & E 7 & [31] & PS1, PS3, PP2, PP3, PP5 & Pathogenic \\
\hline c. $745 \mathrm{C}>\mathrm{T}$ & p.Leu249Phe & E 7 & [32] & PS1, PP2, PP3, PP5 & Likely pathogenic \\
\hline c. $754 \mathrm{C}>\mathrm{T}$ & p.Arg252Trp & E 7 & [33] & PS1, PS3, PP2, PP3, PP5 & Pathogenic \\
\hline c.782G $>\mathrm{A}$ & p.Arg261Gln & E 7 & [33] & PS1, PS3, PP2, PP3, PP5 & Pathogenic \\
\hline c. $814 \mathrm{G}>\mathrm{T}$ & p.Gly272Ter & E 7 & [34] & PVS1, PM4, PP3, PP5 & Pathogenic \\
\hline c. $838 \mathrm{G}>\mathrm{A}$ & p.Glu280Lys & E 7 & [35] & PS1, PS3, PP2, PP3, PP5 & Pathogenic \\
\hline c. $842+1 G>A$ & p.? & I 7 & [36] & PVS1, PP5 & VUS \\
\hline c. $932 \mathrm{~T}>\mathrm{C}$ & p.Leu311Pro & E 9 & [37] & PS1, PS3, PP2, PP3, PP5 & Pathogenic \\
\hline c.1024delG & p.Ala342HisfsTer58 & E 10 & [38] & PVS1, PM2, PM4, PP3, PP5 & Pathogenic \\
\hline c. $1042 C>G$ & p.Leu348Val & E 10 & [26] & PS3, PP2, PP3, PP5 & Likely pathogenic \\
\hline c.1055delG & p.Gly352ValfsTer48 & E 10 & [39] & PVS1, PM4, PP3, PP5 & Pathogenic \\
\hline c. $1066-11 G>A$ & p.Gln355_Tyr356insGlyLeuGln & I 10 & [40] & PS3, PP5 & VUS \\
\hline c. $1162 \mathrm{G}>\mathrm{A}$ & p.Val388Met & E11 & [41] & PS1, PS3, PP2, PP3, PP5 & Pathogenic \\
\hline c. $1169 A>G$ & p.Glu390Gly & E 11 & [42] & PS3, PS1, PP2, PP3, PP5 & Pathogenic \\
\hline c. $1222 \mathrm{C}>\mathrm{T}$ & p.Arg408Trp & E 12 & [43] & PS3, PP2, PP3, PP5 & Likely pathogenic \\
\hline c. $1241 \mathrm{~A}>\mathrm{G}$ & p.Tyr414Cys & E 12 & [44] & PS1, PS3, PP2, PP3, PP5 & Pathogenic \\
\hline c. $1315+1 \mathrm{G}>\mathrm{A}$ & p.? & I 12 & [45] & PVS1, PP5 & VUS \\
\hline
\end{tabular}

Notes: E: exon and I: intron. The most frequent variant was c.1315+1G $>$ A $(8 / 66,11.7 \%)$, followed by c.473G $>A(6 / 66,8.8 \%)$ and c.1162G $>A$ $(6 / 66,8.8 \%)$. In the RS patients, the most common variants were c.1315+1G>A $(7 / 44,15.2 \%), c .1222 \mathrm{C}>\mathrm{T}(6 / 44,13 \%), \mathrm{c} .473 \mathrm{G}>\mathrm{A}(4 / 44,8.7 \%)$, c.754C > T $(4 / 44,8.7 \%)$, and c.1162G>A (4/44, 8.7\%). In the DF patients, c.184delC $(4 / 22,18.1 \%)$, c.782G>A $(3 / 22,13.6 \%)$, and c.1066-11G>A $(3 / 22,13.6 \%)$ were the most common variants.

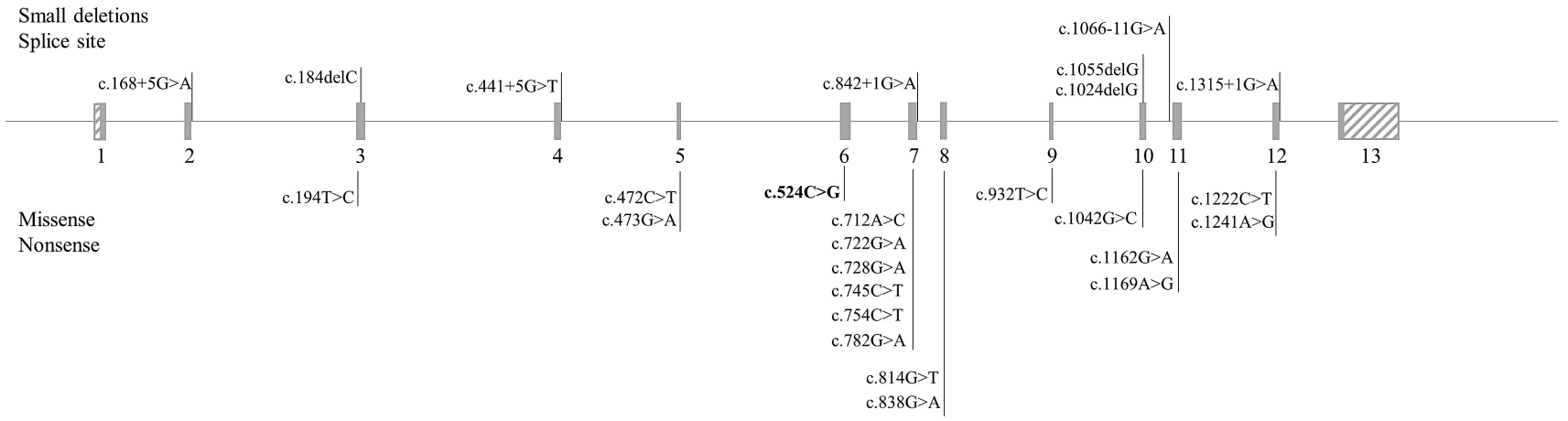

Figure 1. $P A H$ exon structure, and the location of the variants found in the patient sample.

Of the 14 patients without a $\mathrm{BH}_{4}$ responsiveness test, the results of nine were predicted through the BioPKU database: two were responsive, and seven were nonresponsive. Of the total cohort, the results of ten agreed with the BioPKU data. Two RS patients (patients 2 and 7) presented a genotype not described in the BioPKU database [46] and were nonresponsive to $\mathrm{BH}_{4}$, according to the biochemical test $[10,11]$. Also, three DF patients (patients 26, 27 and 31) presented a genotype not described at BioPKU database, being two responsive and one nonresponsive, respectively. 
The novel variant c.524C>G was found in patient 20 , located on exon 6 of the PAH. The ACMG criteria fulfilled by the variant were PM2, PM5, PP2, and PP3, resulting in a likely pathogenic classification. In addition, the patient's clinical information was consistent with classic PKU.

As shown in Figure 2, the novel variant c.524C>G resulted in a proline being substituted with an arginine in position 175 , which is located in the catalytic domain of the PAH protein. This variant does not promote structural alterations in the protein. In the combination of variants p.(Pro175Arg) and p.Arg252Trp, found in the genotype of patient 2, a small portion of monomers showed higher affinity between the subunits than the wild-type complex. The molecular modeling analysis of PAH variants p.Thr238Pro and p.Gly272Ter, found in patient 14, showed differences in the interaction energy between monomers in the PAH tetramer, and most of the different tetramers showed significantly lower affinity than the wild-type (Table S1).
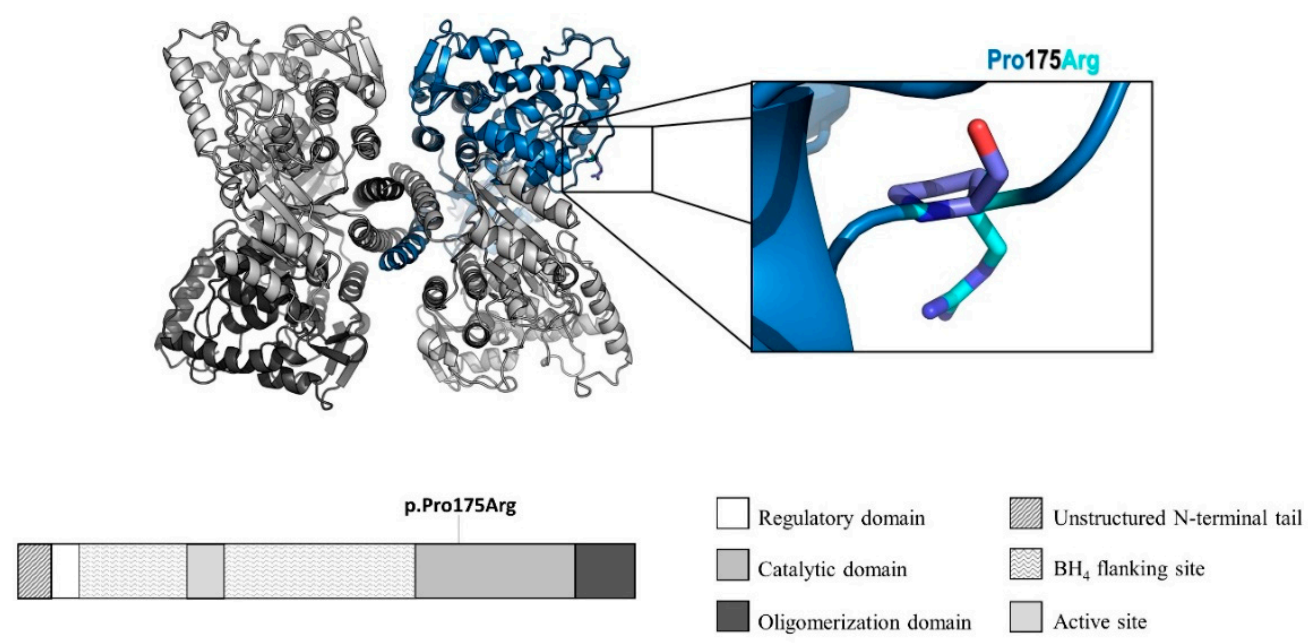

Figure 2. Molecular modeling and protein structure of the PAH enzyme, with the protein location of the novel variant p.Pro175Arg. Adapted from Flydal et al. [18].

\section{Discussion}

PKU is the most common IEM, and its incidence ranges between 1:850-112,000 in Europe (Karachay-Cherkessia Republic (Russia) and Finland, respectively], to 1:10,000 live births in the USA [47]. In Brazil, its incidence is 1:25,000 live births [48], while, in Southern Brazil, its incidence is 1:12,000-16,000 [49]. PKU has been included in Brazil's newborn screening program since 2001 [50]. Despite this screening program, our sample's median age at diagnosis was higher than the Brazilian Ministry of Health recommendations, i.e., up to 28 days of age [6]. A reason for this high median age at diagnosis is the difficulties in the execution of the program, which was implemented only in 2001. Some of our patients were born before that, when each Brazilian state performed a different screening and not all states included PKU in their newborn screening program. This is the reason behind the outstandingly late diagnosis of patients 22.1 and 22.2, diagnosed only after the development of severe symptoms. Besides that, this family is very interesting, since the oldest brother (22.2), who was diagnosed after-and because of-the youngest brother, presented a milder neurological phenotype.

The $P A H$ gene analysis by massive parallel sequencing is a fast, cost-effective, and accurate alternative for the genetic diagnosis of PKU [8,51]. Due to its large size and heterogeneity, similar symptoms are caused by alterations in more than one gene, as in the differential diagnosis of $\mathrm{BH}_{4}$ deficiency and DNAJC12 gene variants. In PKU, especially, a less time-consuming diagnosis can be helpful to avoid the development of neurological symptoms to help predict $\mathrm{BH}_{4}$ responsiveness and to facilitate a differential diagnosis [52].

In this study, the patients' molecular diagnosis agreed in every case with the diagnosis based on biochemical and clinical observations, which confirms the effectiveness of this 
methodology. We identified variants that were not covered in the previous genotyping analysis. In patient 9, for example, the error in previous genotyping could have been the result of a lack of specificity or coverage of the implemented technique or a lack of analysis of the parents' genotypes.

The most frequent variant found in the patients, c.1315+1G>A, was described as a common pathogenic variant in different Northern European populations, especially in Germany [53]. The second-most frequent variant, p.Arg158Gln, is also common in European populations, including Southern Italy and Eastern Europe [53]. The third-most prevalent variant found, p.Val388Met, is described as common in the Iberian Peninsula (5.7\% in Spain and 19\% in Portugal) and has a high frequency in Brazil (9\%) and Chile $(13 \%)$ [54].

The second-most frequent variant in RS patients, p.Arg408Trp, is also common in German populations (24.6\%) [55]. In Southern Brazil, the predominance of European ancestry $(77.7 \%)$ can explain these findings [56]. A previous study of the RS population found p.Ile65Thr (19.5\%), c.169-13T>G (9.7\%), p.Arg261Ter (9.7\%), p.Arg261Gln (9.7\%), p.Val388Met $(9.7 \%)$, and p.Arg $408 \operatorname{Trp}(9.7 \%)$ to be the most frequent variants in this population [23]. However, the frequency of these variations differed in the present study: p.Ile65Thr (2.1\%), p.Arg261Gln (4.3\%), p.Val388Met (8.7\%), p.Arg408Trp (13\%), and the variants c.169-13T>G and p.Arg261Ter were not found. Nevertheless, the small sample size in the previous study should be taken into consideration $(n=16)$. The variants $p$.Arg261Gln and c.1066-11G $>$ A, frequent in patients from $\mathrm{DF}$, have also been described as the most common variants in Portugal [53]. In the DF, which is in the Midwestern region of Brazil, the population's ancestry shows a mixture of Southeastern and Northeastern Brazilian populations, with significant European (63\%) and African (24.1\%) ancestries [57].

A previous study by Acosta et al. (2001) [58] in a Brazilian population (a mixture of Southern, Southeastern, Northeastern, and Midwestern regions) described the most frequent of the pathogenic variants as c.1066-11G >A (17.4\%), p.Arg261Gln (12.2\%), p.Val388Met (9.1\%), p.Arg252Trp (6.5\%), and p.Arg270Lys (4.8\%) [58]. Of these variants, only p.Arg270Lys was not found in the present study. The variants p.Arg261Gln, p.Val388Met, and c.1066-11G >A are also frequent in the States of Mato Grosso do Sul and Minas Gerais [59-61]. The most common pathogenic variants in Argentina and Chile were p.Arg261Gln (10.6\%) and p.Val388Met (17.2\%), respectively [62,63].

The novel variant p.Pro175Arg involves the substitution of a proline for an arginine. The hydrophobic amino acid proline has particular properties: its side chain is connected to the protein backbone. However, unlike proline, which does not display main-chain conformation, arginine, a charged amino acid, is usually found in protein-active or proteinbinding sites [64]. The variant is located in the catalytic domain, although not in a hotspot region with highly destabilizing pathogenic variants between residues 238-330 [18]. The molecular modeling analysis indicates that this substitution can affect the binding between monomers in the PAH tetramer, which could lead to a change in the stability and activity of this enzyme. Another variant, p.Arg252Trp, has 1\% of the PAH activity [65] and is related to the classic PKU.

\section{Conclusions}

The correlation of many variations in the genotypes and their resulting phenotypes is already available in public databases. Thus, a fast genotype diagnosis of PKU patients can help with treatment outcomes. Genotyping is a helpful way to understand how phenylalanine hydroxylase is altered in a patient, the impact of this specific alteration to the enzyme, and the enzyme's level of residual activity with these variants. Additionally, genotyping can help with the patients whose genotypes have information of the $\mathrm{BH}_{4}$ responsiveness; when these patients are responsive, the supplementation with $\mathrm{BH}_{4}$ leads to the enhancement of residual PAH activity, with a chaperone-like effect on a misfolding enzyme subunit [66]. 
This study presents a summary of the clinical and genetic data of 33 unrelated patients from two different regions of Brazil, which confirmed the diagnosis of PAH deficiency in every case. A novel variant was found in the $P A H$ gene.

Supplementary Materials: The following are available online at https:/ /www.mdpi.com/2073-442 $5 / 12 / 1 / 20 / s 1$, Table S1. Differences in binding affinity between monomers in the PAH tetramer in patients 2 and 14 as predicted by the program FoldX 5.0. Interaction energy $(\Delta G)$ between monomers A to D calculated using combinations of the allelles 1 and 2 found in each patient. Differences between the energies of mutant and wild-type proteins $(\Delta \Delta \mathrm{G}=\Delta \mathrm{Gmut}-\Delta \mathrm{Gwt})$ above $1.6 \mathrm{kcal} / \mathrm{mol}$ should significantly affect the stability of the tetramer.

Author Contributions: Conceptualization, R.H.T.; F.S.-L.; T.T.; I.V.D.S.; methodology, R.H.T.; F.S.-L.; T.T.; I.V.D.S.; validation, R.H.T.; formal analysis, R.H.T.; F.S.-L.; R.L.-B.; T.T.; M.T.d.O.C.; R.S.H.; M.T.A.d.S.R.; B.C.M.; M.O.P.; L.C.S.d.S.; F.M.; I.V.D.S.; investigation, R.H.T.; F.S.-L.; T.T.; I.V.D.S.; resources, I.V.D.S.; data curation, R.H.T.; F.S.-L.; T.T.; writing—original draft preparation, R.H.T.; F.S. L.; I.V.D.S.; writing—review and editing, R.H.T.; F.S.-L.; R.L.-B.; T.T.; M.T.d.O.C.; R.S.H.; M.T.A.d.S.R.; B.C.M.; M.O.P.; L.C.S.d.S.; F.M.; I.V.D.S.; supervision, F.S.-L. and I.V.D.S.; project administration, R.H.T.; F.S.-L.; T.T.; I.V.D.S.; funding acquisition, F.S.-L.; T.T.; I.V.D.S. All authors have read and agreed to the published version of the manuscript.

Funding: This study was supported by the FIPE-HCPA (process number 2015-0556), National Coordination for Improvement of Higher Education Personnel (CAPES-Brazil), National Counsel of Technological and Scientific Development (CNPq-Brazil), and the UFRGS Graduate Program in Genetics and Molecular Biology.

Institutional Review Board Statement: This observational, cross-sectional study, with a convenience sampling strategy, was approved by the Hospital de Clínicas de Porto Alegre (HCPA) Research Ethics Committee (no. 2015-0556). All patients recruited for this study or their legal guardians provided written informed consent.

Informed Consent Statement: Informed consent was obtained from all subjects involved in the study or their legal guardians provided written informed consent.

Acknowledgments: The authors would like to thank the patients and legal guardians for participating in this study. We also thank Nenad Blau, who helped us in performing the exclusion of $\mathrm{BH}_{4}$ deficiencies in the patients from RS.

Conflicts of Interest: The authors report no conflict of interest.

\section{References}

1. Blau, N.; Van Spronsen, F.J.; Levy, H.L. Phenylketonuria. Lancet 2010, 376, 1417-1427. [CrossRef]

2. Kochhar, J.S.; Chan, S.Y.; Ong, P.S.; Kang, L. Clinical therapeutics for phenylketonuria. Drug Deliv. Transl. Res. $2012,2,223-237$. [CrossRef]

3. van Spronsen, F.J. Phenylketonuria: A 21st century perspective. Nat. Rev. Endocrinol. 2010, 6, 509-514. [CrossRef] [PubMed]

4. Al Hafid, N.; Christodoulou, J. Phenylketonuria: A review of current and future treatments. Transl. Pediatr. $2015,4,304-317$. [CrossRef] [PubMed]

5. Muntau, A.C.; Röschinger, W.; Habich, M.; Demmelmair, H.; Hoffmann, B.; Sommerhoff, C.P.; Roscher, A.A. Tetrahydrobiopterin as an Alternative Treatment for Mild Phenylketonuria. N. Engl. J. Med. 2002, 347, 2122-2132. [CrossRef]

6. Brasil Ministério da Saúde. Triagem Neonatal Biológica; Ministério da Saúde: Brasília, Brazil, 2016; ISBN 9788533424074.

7. Stenson, P.D.; Mort, M.; Ball, E.V.; Evans, K.; Hayden, M.; Heywood, S.; Hussain, M.; Phillips, A.D.; Cooper, D.N. The Human Gene Mutation Database: Towards a comprehensive repository of inherited mutation data for medical research, genetic diagnosis and next-generation sequencing studies. Hum. Genet. 2017, 136, 665-677. [CrossRef]

8. Cao, Y.Y.; Qu, Y.J.; Song, F.; Zhang, T.; Bai, J.L.; Jin, Y.W.; Wang, H. Fast clinical molecular diagnosis of hyperphenylalaninemia using next-generation sequencing-based on a custom AmpliSeq ${ }^{\mathrm{TM}}$ panel and Ion Torrent PGM sequencing. Mol. Genet. Metab. 2014, 113, 261-266. [CrossRef]

9. Blau, N.; Shen, N.; Carducci, C. Molecular genetics and diagnosis of phenylketonuria: State of the art. Expert Rev. Mol. Diagn. 2014, 14, 655-671. [CrossRef]

10. Giugliani, L.; Sitta, A.; Vargas, C.R.; Santana-da-Silva, L.C.; Nalin, T.; Saraiva-Pereira, M.L.; Giugliani, R.; Schwartz, I.V.D. Responsividade à tetrahidrobiopterina em pacientes com deficiência de fenilalanina hidroxilase. J. Pediatr. 2011, 87, $245-251$. [CrossRef] 
11. Nalin, T.; Perry, I.D.S.; Sitta, A.; Vargas, C.R.; Saraiva-Pereira, M.L.; Giugliani, R.; Blau, N.; Schwartz, I.V.D. Optimized loading test to evaluate responsiveness to tetrahydrobiopterin (BH 4) in Brazilian patients with phenylalanine hydroxylase deficiency. Mol. Genet. Metab. 2011, 104, S80-S85. [CrossRef]

12. Robinson, J.T.; Thorvaldsdóttir, H.; Wenger, A.M.; Zehir, A.; Mesirov, J.P. Variant review with the integrative genomics viewer. Cancer Res. 2017, 77, e31-e34. [CrossRef] [PubMed]

13. Karczewski, K.J.; Francioli, L.C.; Tiao, G.; Cummings, B.B.; Wang, Q.; Collins, R.L.; Laricchia, K.M.; Ganna, A.; Birnbaum, P.; Gauthier, L.D.; et al. The Mutational Constraint Spectrum Quantified from Variation in 141, 456 Humans. Nature 2020, 581, 434-443. [CrossRef]

14. Naslavsky, M.S.; Yamamoto, G.L.; de Almeida, T.F.; Ezquina, S.A.M.; Sunaga, D.Y.; Pho, N.; Bozoklian, D.; Sandberg, T.O.M.; Brito, L.A.; Lazar, M.; et al. Exomic variants of an elderly cohort of Brazilians in the ABraOM database. Hum. Mutat. 2017, 38, 751-763. [CrossRef]

15. Richards, S.; Aziz, N.; Bale, S.; Bick, D.; Das, S.; Gastier-Foster, J.; Grody, W.W.; Hegde, M.; Lyon, E.; Spector, E.; et al. Standards and guidelines for the interpretation of sequence variants: A joint consensus recommendation of the American College of Medical Genetics and Genomics and the Association for Molecular Pathology. Genet. Med. 2015, 17, 405-423. [CrossRef] [PubMed]

16. Garbade, S.F.; Shen, N.; Himmelreich, N.; Haas, D.; Trefz, F.K.; Hoffmann, G.F.; Burgard, P.; Blau, N. Allelic phenotype values: A model for genotype-based phenotype prediction in phenylketonuria. Genet. Med. 2019, 21, 580-590. [CrossRef]

17. Nalin, T.; Perry, I.D.S.; Refosco, L.F.; Oliveira Netto, C.B.; de Souza, C.F.M.; Vieira, T.A.; Picon, P.D.; Schwartz, I.V.D. Phenylketonuria in the Public Health System: Assessment of Adherence. Clin. Biomed. Res. 2010, 30, 225-232.

18. Flydal, M.I.; Alcorlo-Pagés, M.; Johannessen, F.G.; Martínez-Caballero, S.; Skjærven, L.; Fernandez-Leiro, R.; Martinez, A.; Hermoso, J.A. Structure of full-length human phenylalanine hydroxylase in complex with tetrahydrobiopterin. Proc. Natl. Acad. Sci. USA 2019, 166, 11229-11234. [CrossRef]

19. Johansson, M.U.; Zoete, V.; Michielin, O.; Guex, N. Defining and searching for structural motifs using DeepView/SwissPdbViewer. BMC Bioinform. 2012, 13. [CrossRef]

20. Zheng, W.; Zhang, C.; Bell, E.W.; Zhang, Y. I-TASSER gateway: A protein structure and function prediction server powered by XSEDE. Futur. Gener. Comput. Syst. 2019, 99, 73-85. [CrossRef]

21. Guerois, R.; Nielsen, J.E.; Serrano, L. Predicting changes in the stability of proteins and protein complexes: A study of more than 1000 mutations. J. Mol. Biol. 2002, 320, 369-387. [CrossRef]

22. Ferreira, P.; Sant'Anna, O.; Varejão, N.; Lima, C.; Novis, S.; Barbosa, R.V.; Caldeira, C.M.; Rumjanek, F.D.; Ventura, S.; Cruz, M.W.; et al. Structure-based analysis of A19D, a variant of transthyretin involved in familial amyloid cardiomyopathy. PLoS ONE 2013, 8, e82484. [CrossRef]

23. Da Santana Silva, L.C.; Santos Carvalho, T.; Da Britto Silva, F.; Morari, L.; Aguirres Fachel, Â.; Pires, R.; Farret Refosco, L.; Desnick, R.J.; Giugliani, R.; Saraiva Pereira, M.L.; et al. Molecular characterization of phenylketonuria in South Brazil. Mol. Genet. Metab. 2003, 79, 17-24. [CrossRef]

24. Zekanowski, C.; Nowacka, M.; Cabalska, B.; Bal, J. Molecular basis of mild hyperphenylalaninaemia in Poland. J. Med. Genet. 1997, 34, 1035-1036. [CrossRef] [PubMed]

25. Daniele, A.; Cardillo, G.; Pennino, C.; Carbone, M.T.; Scognamiglio, D.; Correra, A.; Pignero, A.; Castaldo, G.; Salvatore, F. Molecular Epidemiology of Phenylalanine Hydroxylase Deficiency in Southern Italy: A 96\% Detection Rate with Ten Novel Mutations. Ann. Hum. Genet. 2007, 71, 185-193. [CrossRef] [PubMed]

26. Eisensmith, R.C.; Woo, S.L.C. Molecular basis of phenylketonuria and related hyperphenylalaninemias: Mutations and polymorphisms in the human phenylalanine hydroxylase gene. Hum. Mutat. 1992, 1, 13-23. [CrossRef] [PubMed]

27. Yamashita, K.; Takarada, Y.; Otsuka, N.; Kagawa, S.; Matsuoka, A.; Kalanin, J. Genetic diagnosis of phenylketonuria: Identification of the mutations of phenylalanine hydroxylase gene by PCR direct sequencing. Rinsho Byori. 1992, 40, 1060-1066.

28. Dworniczak, B.; Aulehla-Scholz, C.; Horst, J. Phenylketonuria: Detection of a frequent haplotype 4 allele mutation. Hum. Genet. 1989, 84, 95-96. [CrossRef]

29. Dworniczak, B.; Kalaydjieva, L.; Pankoke, S.; Aulehla-Scholz, C.; Allen, G.; Horst, J. Analysis of exon 7 of the human phenylalanine hydroxylase gene: A mutation hot spot? Hum. Mutat. 1992, 1, 138-146. [CrossRef]

30. Guldberg, P.; Romano, V.; Ceratto, N.; Bosco, P.; Ciuna, M.; Indelicato, A.; Mollica, F.; Meli, C.; Giovannini, M.; Riva, E. Mutational spectrum of phenylalanine hydroxylase deficiency in Sicily: Implications for diagnosis of hyperphenylalaninemia in southern Europe. Hum. Mol. Genet. 1993, 2, 1703-1707. [CrossRef]

31. Wang, T.; Okano, Y.; Eisensmith, R.C.; Lo, W.H.Y.; Huang, S.-Z.; Zeng, Y.-T.; Yuan, L.-F.; Liu, S.-R.; Woo, S.L.C. Missense mutations prevalent in orientals with phenylketonuria: Molecular characterization and clinical implications. Genomics 1991, 10, 449-456. [CrossRef]

32. Zschocke, J.; Graham, C.A.; Carson, D.J.; Nevin, N.C. Phenylketonuria mutation analysis in Northern Ireland: A rapid stepwise approach. Am. J. Hum. Genet. 1995, 57, 1311-1317. [PubMed]

33. Abadie, V.; Lyonnet, S.; Maurin, N.; Berthelon, M.; Caillaud, C.; Giraud, F.; Mattei, J.F.; Rey, J.; Rey, F.; Munnich, A. CpG dinucleotides are mutation hot spots in phenylketonuria. Genomics 1989, 5, 936-939. [CrossRef]

34. Svensson, E.; Andersson, B.; Hagenfeldt, L. Two mutations within the coding sequence of the phenylalanine hydroxylase gene. Hum. Genet. 1990, 85, 300-304. [CrossRef] [PubMed] 
35. Lyonnet, S.; Caillaud, C.; Rey, F.; Berthelon, M.; Frézal, J.; Rey, J.; Munnich, A. Molecular genetics of phenylketonuria in Mediterranean countries: A mutation associated with partial phenylalanine hydroxylase deficiency. Am. J. Hum. Genet. 1989, 44, 511-517.

36. Dianzani, I.; Forrest, S.M.; Camaschella, C.; Saglio, G.; Ponzone, A.; Cotton, R.G. Screening for mutations in the phenylalanine hydroxylase gene from Italian patients with phenylketonuria by using the chemical cleavage method: A new splice mutation. Am. J. Hum. Genet. 1991, 48, 631-635.

37. Lichter-Konecki, U.; Konecki, D.S.; DiLella, A.G.; Brayton, K.; Marvit, J.; Hahn, T.M.; Trefz, F.K.; Woo, S.L.C. Phenylalanine Hydroxylase Deficiency Caused by a Single Base Substitution in an Exon of the Human Phenylalanine Hydroxylase Gene. Biochemistry 1988, 27, 2881-2885. [CrossRef]

38. Guldberg, P.; Rey, F.; Zschocke, J.; Romano, V.; François, B.; Michiels, L.; Ullrich, K.; Hoffmann, G.F.; Burgard, P.; Schmidt, H.; et al A European Multicenter Study of Phenylalanine Hydroxylase Deficiency: Classification of 105 Mutations and a General System for Genotype-Based Prediction of Metabolic Phenotype. Am. J. Hum. Genet. 1998, 63, 71-79. [CrossRef]

39. Rozen, R.; Mascisch, A.; Lambert, M.; Laframboise, R.; Scriver, C.R. Mutation profiles of phenylketonuria in Quebec populations: Evidence of stratification and novel mutations. Am. J. Hum. Genet. 1994, 55, 321-326.

40. Dworniczak, B.; Aulehla-Scholz, C.; Kalaydjieva, L.; Bartholomé, K.; Grudda, K.; Horst, J. Aberrant splicing of phenylalanine hydroxylase mRNA: The major cause for phenylketonuria in parts of southern Europe. Genomics 1991, 11, 242-246. [CrossRef]

41. Guldberg, P.; Henriksen, K.F.; Güttler, F. Molecular Analysis of Phenylketonuria in Denmark: 99\% of the Mutations Detected by Denaturing Gradient Gel Electrophoresis. Genomics 1993, 17, 141-146. [CrossRef]

42. Guldberg, P.; Henriksen, K.F.; Thöny, B.; Blau, N.; Güttler, F. Molecular Heterogeneity of Nonphenylketonuria Hyperphenylalaninemia in 25 Danish Patients. Genomics 1994, 21, 453-455. [CrossRef]

43. DiLella, A.G.; Marvit, J.; Brayton, K.; Woo, S.L. An amino-acid substitution involved in phenylketonuria is in linkage disequilibrium with DNA haplotype 2. Nature 1987, 327, 333-336. [CrossRef]

44. Okano, Y.; Eisensmith, R.C.; Güttler, F.; Lichter-Konecki, U.; Konecki, D.S.; Trefz, F.K.; Dasovich, M.; Wang, T.; Henriksen, K.; Lou, H.; et al. Molecular Basis of Phenotypic Heterogeneity in Phenylketonuria. N. Engl. J. Med. 1991, 324, 1232-1238. [CrossRef] [PubMed]

45. DiLella, A.G.; Kwok, S.C.M.; Ledley, F.D.; Marvit, J.; Woo, S.L.C. Molecular Structure and Polymorphic Map of the Human Phenylalanine Hydroxylase Gene. Biochemistry 1986, 25, 743-749. [CrossRef] [PubMed]

46. Romani, C.; Palermo, L.; MacDonald, A.; Limback, E.; Hall, S.K.; Geberhiwot, T. The impact of phenylalanine levels on cognitive outcomes in adults with phenylketonuria: Effects across tasks and developmental stages. Neuropsychology 2017, 31, 242-254 [CrossRef]

47. Hillert, A.; Anikster, Y.; Belanger-Quintana, A.; Burlina, A.; Burton, B.K.; Carducci, C.; Chiesa, A.E.; Christodoulou, J.; Đorđević, M.; Desviat, L.R.; et al. The Genetic Landscape and Epidemiology of Phenylketonuria. Am. J. Hum. Genet. 2020, 107, 234-250. [CrossRef] [PubMed]

48. Vieira Neto, E.; Maia Filho, H.S.; Monteiro, C.B.; Carvalho, L.M.; Tonon, T.; Vanz, A.P.; Schwartz, I.V.D.; Ribeiro, M.G. Quality of life and adherence to treatment in early-treated Brazilian phenylketonuria pediatric patients. Braz. J. Med. Biol. Res. 2018, 51, 1-10. [CrossRef]

49. Trevisan, L.M.; Nalin, T.; Tonon, T.; Veiga, L.M.; Vargas, P.; Krug, B.C.; Leivas, P.G.C.; Schwartz, I.V.D. Access to treatment for phenylketonuria by judicial means in Rio Grande do Sul, Brazil. Cien. Saude Colet. 2015, 20, 1607-1616. [CrossRef]

50. Ministério da Saúde do Brasil. Portaria No 822, de 06 de Junho de 2001; Ministério da Saúde: Brasília, Brazil, 2001.

51. Li, N.; Jia, H.; Liu, Z.; Tao, J.; Chen, S.; Li, X.; Deng, Y.; Jin, X.; Song, J.; Zhang, L.; et al. Molecular characterisation of phenylketonuria in a Chinese mainland population using next-generation sequencing. Sci. Rep. 2015, 5, 15769. [CrossRef]

52. Karačić, I.; Meili, D.; Sarnavka, V.; Heintz, C.; Thöny, B.; Ramadža, D.P.; Fumić, K.; Mardešić, D.; Barić, I.; Blau, N. Genotypepredicted tetrahydrobiopterin (BH4)-responsiveness and molecular genetics in Croatian patients with phenylalanine hydroxylase (PAH) deficiency. Mol. Genet. Metab. 2009, 97, 165-171. [CrossRef]

53. Zschocke, J. Phenylketonuria mutations in Europe. Hum. Mutat. 2003, 21, 345-356. [CrossRef]

54. Desviat, L.R.; Pérez, B.; De Lucca, M.; Cornejo, V.; Schmidt, B.; Ugarte, M. Evidence in Latin America of recurrence of V388M, a phenylketonuria mutation with high in vitro residual activity. Am. J. Hum. Genet. 1995, 57, 337-342. [PubMed]

55. Aulehla-Scholz, C.; Heilbronner, H. Mutational spectrum in German patients with phenylalanine hydroxylase deficiency. Hum. Mutat. 2003, 21, 399-400. [CrossRef] [PubMed]

56. Pena, S.D.J.; di Pietro, G.; Fuchshuber-Moraes, M.; Genro, J.P.; Hutz, M.H.; de Kehdy, F.S.G.; Kohlrausch, F.; Magno, L.A.V.; Montenegro, R.C.; Moraes, M.O.; et al. The genomic ancestry of individuals from different geographical regions of Brazil is more uniform than expected. PLoS ONE 2011, 6, e17063. [CrossRef] [PubMed]

57. de Souza, A.M.; Resende, S.S.; de Sousa, T.N.; de Brito, C.F.A. A systematic scoping review of the genetic ancestry of the brazilian population. Genet. Mol. Biol. 2019, 42, 495-508. [CrossRef] [PubMed]

58. Acosta, A.X.; Silva, W.A.; Carvalho, T.M.; Gomes, M.; Zago, M.A. Mutations of the phenylalanine hydroxylase (PAH) gene in Brazilian patients with phenylketonuria. Hum. Mutat. 2001, 17, 122-130. [CrossRef]

59. Costa, R.D.; Galera, B.B.; Rezende, B.C.; Venâncio, A.C.; Galera, M.F. Identification of mutations in the PAH gene in PKU patients in the state of Mato Grosso. Rev. Paul. Pediatr. 2020, 38. [CrossRef] 
60. dos Santos, L.L.; Magalhães, M.D.C.; Reis, A.D.O.; Starling, A.L.P.; Januário, J.N.; da Fonseca, C.G.; de Aguiar, M.J.B.; Carvalho, M.R.S. Frequencies of phenylalanine hydroxylase mutations I65T, R252W, R261Q, R261X, IVS10nt11, V388M, R408W, Y414C, and IVS12nt1 in Minas Gerais, Brazil. Genet. Mol. Res. 2006, 5, 16-23.

61. Santos, L.L.; Castro-Magalhães, M.; Fonseca, C.G.; Starling, A.L.P.; Januário, J.N.; Aguiar, M.J.B.; Carvalho, M.R.S. PKU in Minas Gerais State, Brazil: Mutation Analysis. Ann. Hum. Genet. 2008, 72, 774-779. [CrossRef]

62. Enacán, R.E.; Miñana, M.N.; Fernandez, L.; Valle, M.G.; Salerno, M.; Fraga, C.I.; Santos-Simarro, F.; Prieto, L.; Lapunzina, P.; Specola, N.; et al. Phenylalanine Hydroxylase (PAH) Genotyping in PKU Argentine Patients. J. Inborn Errors Metab. Screen. 2019, 7. [CrossRef]

63. Hamilton, V.; Santa María, L.; Fuenzalida, K.; Morales, P.; Desviat, L.R.; Ugarte, M.; Pérez, B.; Cabello, J.F.; Cornejo, V. Characterization of Phenyalanine Hydroxylase Gene Mutations in Chilean PKU Patients. In JIMD Reports; Springer: Heidelberg, Germany, 2018; Volume 4, pp. 71-77. ISBN 978-3-642-32441-3.

64. Betts, M.J.; Russell, R.B. Amino-Acid Properties and Consequences of Substitutions. In Bioinformatics for Geneticists; John Wiley \& Sons, Ltd.: Chichester, UK, 2006; Volume 9, pp. 311-342. ISBN 9780470026199.

65. Dobrowolski, S.F.; Heintz, C.; Miller, T.; Ellingson, C.; Ellingson, C.; Özer, I.; Gökçay, G.; Baykal, T.; Thöny, B.; Demirkol, M.; et al. Molecular genetics and impact of residual in vitro phenylalanine hydroxylase activity on tetrahydrobiopterin responsiveness in Turkish PKU population. Mol. Genet. Metab. 2011, 102, 116-121. [CrossRef] [PubMed]

66. Sarkissian, C.N.; Gamez, A.; Scott, P.; Dauvillier, J.; Dorenbaum, A.; Scriver, C.R.; Stevens, R.C. Chaperone-Like Therapy with Tetrahydrobiopterin in Clinical Trials for Phenylketonuria: Is Genotype a Predictor of Response. In JIMD Reports; Springer: Heidelberg, Germany, 2011; Volume 4, pp. 59-70. ISBN 978-3-642-32441-3. 